\title{
8 Soil fertility maintenance and nutrient management for agricultural transformation
}

\author{
Bernard Vanlauwe, Pauline Chivenge \\ and Shamie Zingore
}

\section{Introduction}

Sub-Saharan Africa (SSA) continues to experience growing food insecurity underpinned by low crop productivity and rapid population growth (FAO et al., 2018). The problems of low crop productivity and malnutrition are most severe in Southern Africa (Misselhorn, 2005) due to widespread problems of soil fertility depletion, land degradation and unfavourable climatic conditions (Nyamangara et al., 2000; Msangi, 2007). Yields for cereal crops in smallholder farming systems in Southern Africa are less than 30\% of attainable yields, and low use of fertilizer and other nutrient resources are recognized as one of the major limiting factors. That said, overall crop production has quadrupled over the past seven decades, with the relative contribution of area expansion and productivity increase varying between various countries. For example, between 1961 and 2017 maize productivity increase supported by increased fertilizer use contributed substantially to maize production increase in Zambia and Malawi (Table 8.1). In contrast, maize yields and fertilizer use have remained low in Mozambique, and area expansion has accounted for the largest maize production increase (Table 8.1).

Large areas where crops are produced with little or no fertilizer and organic nutrient inputs are characterized by severe loss in carbon stocks, biodiversity and ecosystem service provision in natural vegetation and soils (Zingore et al., 2005; Vlek et al., 2008). The majority of soils in Southern Africa are inherently infertile due to a bedrock that consists of mostly granites and gneiss (Deckers et al., 2000). Although average fertilizer use has remained low in Africa at about $16 \mathrm{~kg}$ nutrients $\mathrm{ha}^{-1}$, national fertilizer use data show a growing number of countries in Southern Africa achieving at least $30 \mathrm{~kg}$ nutrients ha ${ }^{-1}$. Further significant increase in fertilizer and other organic resources will be required to offset negative nutrient balances regionally (Fixen et al., 2015).

To be effective, technologies for increasing productivity must be adapted to the complex and highly variable biophysical and socioeconomic conditions in smallholder farming systems. At the regional scale, agro-ecological and soil conditions have led to diverse farming systems with different crops, cropping patterns, soil management considerations and access to inputs and commodity 
Table 8.1 Changes in maize yield, production areas and recent fertilizer use for Malawi, Mozambique and Zambia in Southern Africa

\begin{tabular}{llllllll}
\hline Country & $\begin{array}{l}\text { Base yield } \\
1961 \\
(t / h a)\end{array}$ & $\begin{array}{l}\text { Yield } \\
2017 \\
(t / h a)\end{array}$ & $\begin{array}{l}\text { Yield } \\
\text { Increase } \\
(\%)\end{array}$ & $\begin{array}{l}\text { Base Area } \\
\text { 1961 } \\
\text { (million ha) }\end{array}$ & $\begin{array}{l}\text { Area 2017 } \\
\text { (million ha) }\end{array}$ & $\begin{array}{l}\text { Area } \\
\text { Increase } \\
(\%)\end{array}$ & $\begin{array}{l}\text { Fertilizer NPK } \\
\text { nutrient use } \\
2016(\mathrm{~kg} / \mathrm{ha})\end{array}$ \\
\hline Malawi & 1.02 & 2.01 & 97 & 0.80 & 1,73 & 116 & 21.6 \\
Mozambique & 0.87 & 0.93 & 7 & 0.43 & 1,83 & 331 & 3.7 \\
Zambia & 0.88 & 2.52 & 186 & 0.75 & 1,43 & 91 & 58.5 \\
\hline
\end{tabular}

Source: FAOSTAT: www.fao.org.

markets. Within farming communities, distinctive features that characterize smallholder farming systems in Southern Africa as in most of sub-Saharan Africa (SSA) is the wide diversity of farming households and marked heterogeneity for both biophysical and socioeconomic conditions (Zingore et al., 2011; Kamanga et al., 2009). The intensity of nutrient use varies between farms of different resource endowment and production orientation, leading to variation in soil fertility status and crop productivity at the farm level. In smallholder farming systems resources are general preferentially allocated to fields closer to the homestead largely due to shortage of inputs and labour (Mtambanengwe and Mapfumo, 2005; Tittonell et al., 2010). This has created soil fertility gradients on the farms, with lower fertility on the outfields, and these also vary depending on farm typology and soil types.

\section{Soil fertility decline: a slow variable that can result in non-responsiveness}

Traditionally, soil fertility in African smallholder farming systems was regenerated through shifting cultivation where land was cleared and cropped for a few years followed by multiyear fallow periods. However, increasing population pressure has eroded fallows in Southern Africa and resulted in continuous cropping, usually without crop rotations, with inadequate inputs due to limited resources, resulting in nutrient mining. Soil fertility decline has led to corresponding declines in crop productivity (Mtambanengwe and Mapfumo, 2005; Zingore et al., 2011). Consequently, this has resulted in declining above- and below-ground biomass that can be returned to the soil as source of $\mathrm{C}$ and nutrients. A study in the Eastern Cape Province of South Africa showed that soil fertility was low for cultivated land in smallholder fields largely due to inadequate nutrient inputs compared to their commercial counterparts (Mandiringana et al., 2005). These soils were associated with a critically low $\mathrm{pH}$, suggesting that crop response to fertilizer addition may be low if soils are not limed. The combination of low soil organic matter, lack of surface cover and lack of crop rotations makes the soils in smallholder farming systems susceptible to erosion, further degrading the soils, with effects being greater on coarse rather than fine textured soils. 
Soil fertility degradation on sandy soils tends to have greater repercussions on crop productivity than clayey soils (Rusinamhodzi et al., 2013; Vanlauwe et al., 2015). Clayey soils, on the other hand, tend to have greater soil organic matter due to greater physical protection (Chivenge et al., 2007), giving them greater buffering capacity and less sensitivity to degradation. Sandy soils generally have lower water and nutrient holding capacity, low soil organic matter and low soil pH. Exchangeable basic cations are low in sandy soils and are depleted on degraded sandy soils, contributing to low crop productivity and soil acidification, especially when continuously cropped without addition of organic fertilizers (Juo et al., 1995). Application of mineral fertilizers in such soils often gives small yield responses with low returns to investment and low resource use efficiencies. These soils are known as non-responsive due to other limitations affecting crop response including micronutrients and soil $\mathrm{pH}$ (Vanlauwe et al., 2010). That study further outlined that addition of organic resources or other amendments in non-responsive soils is necessary if any return to fertilizer investment is to be realized.

The ability of soil management practices to restore crop productivity of degraded soil depends on the extent and the path of the degradation process; a phenomenon analogous to hysteresis (Tittonell et al., 2008). The restoration of soil fertility and crop productivity, with the combined application of manure with mineral fertilizer, has been observed to be faster on a degraded clayey than degraded sandy soil (Rusinamhodzi et al., 2013). Moreover, it was possible to restore soil fertility and crop productivity with the application of mineral fertilizers on the clayey soil but not on the sandy soil. This emphasizes the need for repeated application of organic resources on degraded non-responsive soils before benefit from applied mineral fertilizers can be realized.

Restoration of soil fertility in degraded sandy soils often requires the addition of organic materials due to multiple nutrient deficiencies, coupled with acidity in some cases (Zingore et al., 2011). Similarly, fast-growing trees have been used in Southern Africa to enhance soil fertility and improve crop yields (Sileshi et al., 2012) since these can access nutrients and water from deeper, often less sandy soil horizons (Pierret et al., 2016). Organic materials contain macronutrients and micronutrients to alleviate the multi-nutrient deficiencies. In addition, the slow release of nutrients from organic materials offers greater synchrony between demand and supply of nutrients, particularly for sandy soils where nutrients tend to leach easily. In a nine year study in Murewa, Zimbabwe, Rusinamhodzi et al. (2013) observed that mineral fertilizer alone was not adequate to restore fertility of degraded sandy soils. However, even with addition of large quantities of manure, crop productivity and soil organic carbon build-up was delayed in degraded sandy soils compared to degraded clayey soils. They attributed this to multiple nutrient deficiencies associated with inherent low fertility and nutrient depletion due to previous management. Availability of manure is limited to farmers who own livestock, while those who do not have livestock often have their fields grazed by livestock from their neighbours, further exporting nutrients from poor farmers' fields. The quantity of manure 
on smallholder farming systems is often inadequate to apply to the whole farm even for farmers who own livestock (Zingore et al., 2011). Consequently, the restoration of degraded sandy soils remains a challenge, especially for resource poor smallholder farmers.

\section{Need for sustainable intensification and improved soil fertility status}

Smallholder agriculture in sub-Saharan Africa (SSA) needs to either intensify expanding agricultural land is no longer an option for densely populated areas, or ensure that natural ecosystems, such as the forest in the Congo Basin, are preserved. Even in areas where land expansion still occurs, intensification of agricultural production is needed to keep pace with an ever-growing population. The discourse on intensification is currently framed as "Sustainable Intensification" (SI) and commonly encompasses three dimensions: 1) increased productivity; 2) maintenance of ecosystem services; and 3) increased resilience to shocks (e.g., Pretty et al., 2011; Vanlauwe et al., 2014), accompanied by a set of dimensions that enable the generation of previous outputs in the human, social and economic realm (Snapp et al., 2018). Sustainable Intensification thus aims at generating the required food for a growing population while operating within the planetary boundaries (Rockström et al., 2009) and addressing important drivers of change affecting crop yields such as climate change.

Soil fertility interacts with each of the previous dimensions and is thus key to the delivery of SI. First, increased crop yields require improved soil fertility conditions, and more so in SSA where smallholder agriculture has been based largely on the mining of soil nutrient stocks. This concerns mainly those soil fertility components that interact directly with crop growth including the supply of nutrients, the control of soil moisture dynamics, the provisioning of appropriate soil physical conditions for root growth and the regulation of soil biota that affect plant growth. Second, soil fertility provides a number of important ecosystem services that are not directly related to crop growth. These include the regulation of nutrient and water use efficiencies, the accumulation of atmospheric $\mathrm{CO} 2$ and the control of erosion. Considering that the soil organic matter status is probably one of the most important indicators for soil fertility status, Figure 8.1 sketches conceptually how soil fertility status can interact with the provision of crop productivity and other soil-based ecosystem services. Lastly, fertile soils can reduce the effects of weather- or pest and disease-related stresses by providing improved rooting and soil moisture conditions or supporting healthier plants, respectively. In a sense, one could argue that SI will not happen under poor soil fertility conditions.

\section{Integrated soil fertility management - a path towards SI?}

If SI is unlikely under poor soil fertility conditions, and since most soils under smallholder farming are degraded to a certain extent because of nutrient mining and associated degradation processes, it follows that improvement of soil 


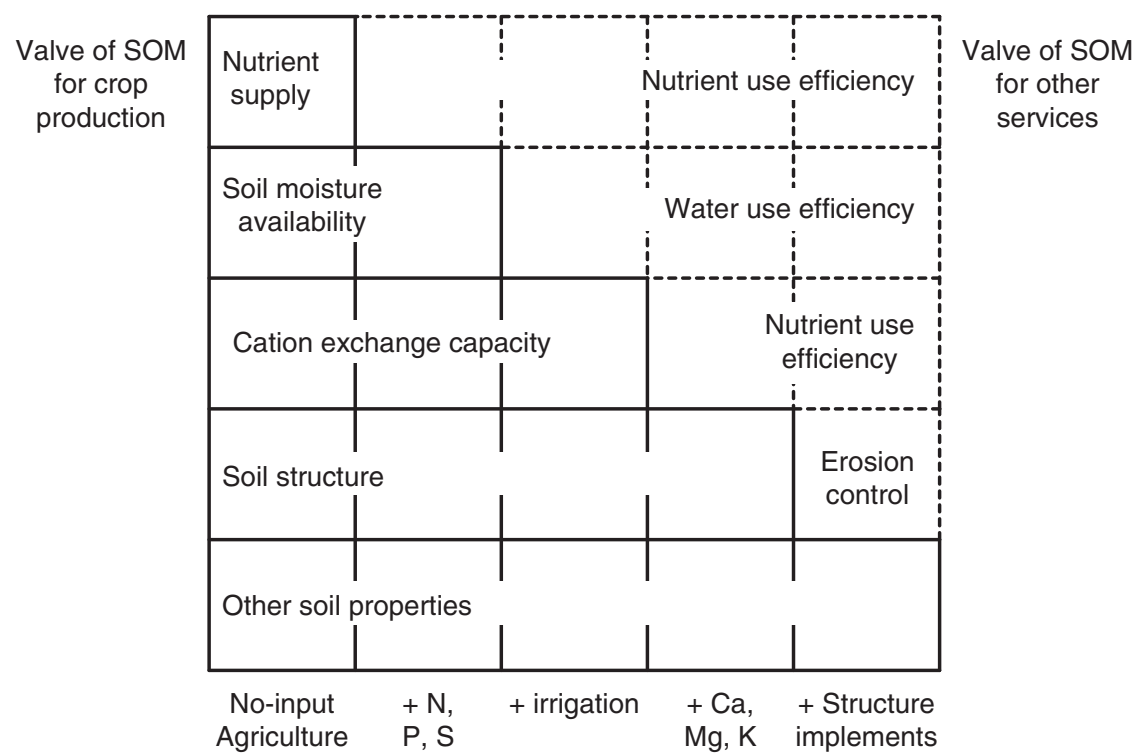

Figure 8.1 Conceptually depicted functions of the soil organic matter (SOM) pool in relation to crop production and other environmental services; note that the sketch does not include a relative valuation of each of the functions

fertility is a prerequisite on the path towards SI. Several technologies and combinations thereof have been conceptualized, promoted and evaluated over time, including those aiming at seeking alternatives to fertilizer (Figure 8.2). Over the years, however, it was found that technologies that do not generate immediate improvements in crop yield are unlikely to be adopted by large numbers of smallholder farmers since they face large risks for food insecurity and compete with labour for other production units (Vanlauwe et al., 2017). While in the 1970s, a lot of work was initiated on fertilizer use and appropriate land preparation methods, during the 1980s and 1990s the balance was swung away from fertilizer towards more organic matter-based systems. Since the latter did not provide those immediate benefits to the farmers during the last ten to 15 years, soil fertility management R\&D is now often placed in the context of Integrated Soil Fertility Management (Vanlauwe et al., 2010; Vanlauwe et al., 2015).

Integrated Soil Fertility Management has been defined as:

A set of soil fertility management practices that necessarily include the use of fertilizer, organic inputs and improved germplasm, combined with the knowledge of how to adapt these practices to local conditions, aimed at maximizing agronomic use efficiency of the applied nutrients and improving crop productivity. All inputs need to be managed following sound agronomic principles.

(Vanlauwe et al., 2010) 


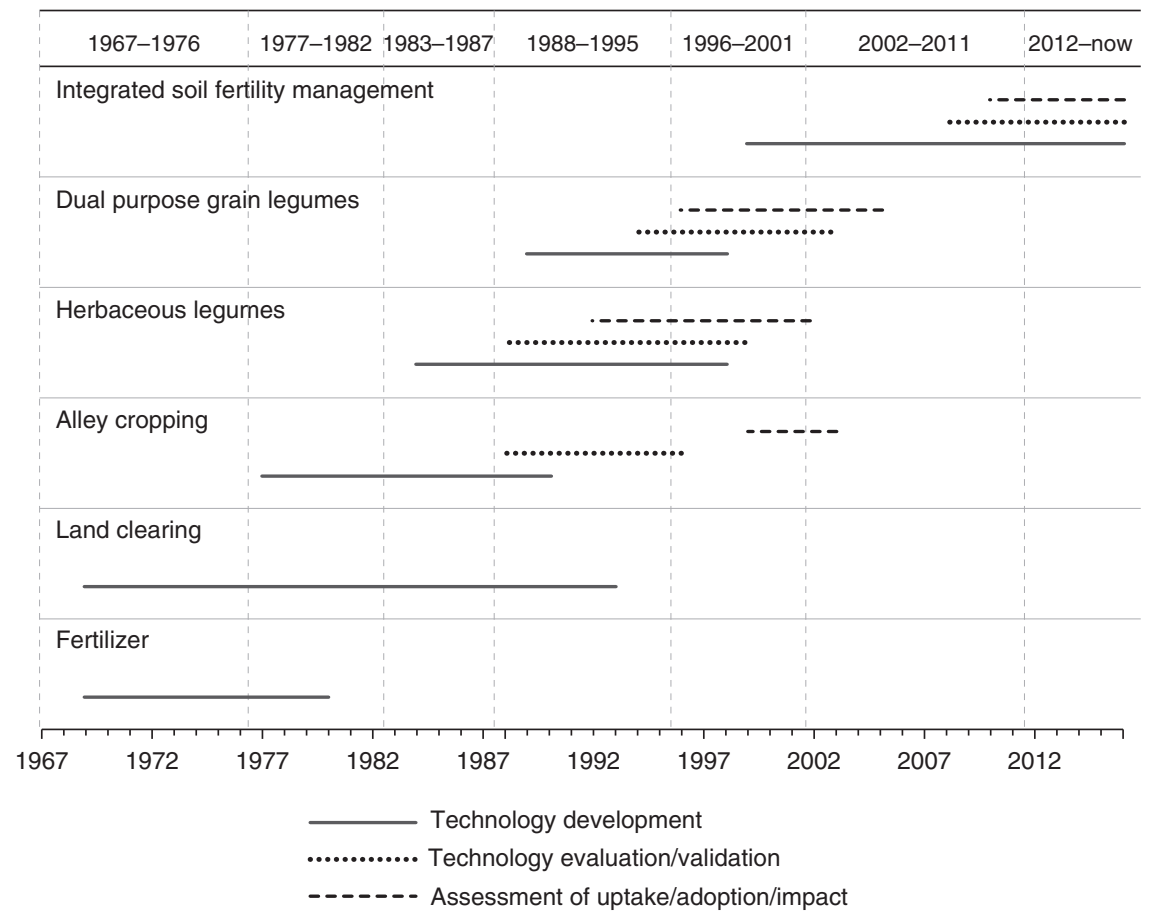

Figure 8.2 Evolution of the technologies and interventions prioritized by soil and soil fertility research initiatives at the International Institute of Tropical Agriculture, with an indication of the technology development, evaluation/validation and uptake/ adoption/impact phases from 1967 to the present

Source: Vanlauwe et al., 2017

Although conclusive evidence is limited, data from certain long-term trials confirm that ISFM practices increase crop yields, enhance soil $\mathrm{C}$ and are more stable over time (e.g., Vanlauwe et al., 2005).

\section{ISFM applied to Southern Africa and implications for policy}

Soils in smallholder farming systems have high spatial heterogeneity within short distances either due to parent material or management, associated with resource availability and farmer typology. Nutrient management in those situations needs to be tailored to suit different site-specific conditions, instead of the blanket recommendations that have been promoted by extension. While ISFM has been shown to improve crop yields compared to no input control or sole applied organic or mineral fertilizer, yield gains tend to be influenced by soil type and agro-climatic conditions. On sandy soils, addition of organic resources 
tends to improve water productivity, particularly in drier areas, thereby influencing the utilization efficiency of added mineral fertilizers. ISFM has been shown to improve maize yields and restore soil fertility compared to sole mineral fertilizer, especially on degraded sandy soils (Rusinamhodzi et al., 2013). This is because the organic resources contribute secondary nutrients and micronutrients that are deficient in degraded soils, thereby enhancing the utilization efficiency of the mineral fertilizers. In a study in Eastern Zimbabwe, ISFM was shown to be more effective at restoring soil fertility and improving maize yields when herbaceous legumes were included in the cropping sequence (Nezomba et al., 2015). This is important for smallholder farmers without adequate mineral fertilizers and organic manures to restore degraded soils.

Climate change predictions in Southern Africa estimate declining precipitation associated with high interannual variability and increasing temperature (Conway et al., 2015). This has been predicted to cause reductions in maize productivity. Using simulation modelling using future climate scenarios, Rurinda et al. (2015) predicted that fertilizer addition would increase crop yields in current and future climates but yield gain with fertilizer decreased over time, suggesting that nutrient management will remain important in future climates in order to avoid loss of crop productivity. Thus, breeding efforts to improve drought tolerance would need to be considered, together with shifts towards crops that are more drought tolerant such as sorghum and millets.

\section{The need for appropriate policy initiatives to guide agricultural transformation}

The uptake of ISFM towards the transformation of smallholder agriculture in Southern Africa is highly dependent on institutional and government policies. Investments on ISFM are going to be driven by land security, with farmers likely to invest when there is land tenure security or ownership. Addressing the land tenure issue in smallholder farming systems in Southern Africa will also be important to leverage farmers' access to financial services, since most of the farmers operate at marginal economic levels. This will also require linking farmers to input and output markets, to enable farmers to sell their produce at favourable prices and avoid being short-changed by middlemen and ensure access to inputs (Koppmair et al., 2017). Access to inputs needs to be improved, since one of the key elements of ISFM is the use of fertilizers, which are generally not available or expensive for smallholder farmers. Consequently, the successful uptake of ISFM would be high if governments ensure timely availability of fertilizers and, where possible offer smart subsidies for both fertilizers and good quality seeds. Such incentives can be linked to ICT, for faster and wider information delivery through mobile phones, taking advantage of high cellphone use in smallholder farming systems (Aker and Mbiti, 2010). ICT is useful across the whole value chain including development of tools for deployment of ISFM recommendations to farmers, translated from highly technical and knowledge-intensive format into readily understandable and actionable 


\section{Bernard Vanlauwe et al.}

formats. This will also require investments in training extension agents who can deliver ISFM information to farmers and ensure local adaptation of ISFM depending on ecological and socioeconomic conditions.

\section{References}

Aker, J.C. and Mbiti, I.M. (2010) 'Mobile phones and economic development in Africa', Journal of Economic Perspectives, vol 24, pp. 207-232.

Chivenge, P.P., Murwira, H.K., Giller, K.E., Mapfumo, P. and Six, J. (2007) 'Long-term impact of reduced tillage and residue management on soil carbon stabilization: Implications for conservation agriculture on contrasting soil', Soil and Tillage Research, vol 94, pp. 328-337.

Conway, D., Van Garderen, E.A., Deryng, D., Dorling, S., Krueger, T., Landman, W., Lankford, B., Lebek, K., Osborn, T. and Ringler, C. (2015) 'Climate and southern Africa's water - energy - food nexus', Nature Climate Change, vol 5, p. 837.

Deckers, J., Laker, M., Vanherreweghe, S., Vanclooster, M., Swennen, R. and Cappuyns, V. (2000) 'State of the art on soil-related geo-medical issues in the world', in J. Låg (ed) Geomedical Problems in Developing Countries. Norwegian Academy of Science and Letters, Oslo.

FAO, IFAD, UNICEF, WFP and WHO. (2018) The State of Food Security and Nutrition in the World 2018. Building Climate Resilience for Food Security and Nutrition. FAO, Rome.

Fixen, P., Brentrup, F., Bruulsema, T., Garcia, F., Norton, R. and Zingore, S. (2015) 'Nutrient/fertilizer use efficiency: Measurement, current situation and trends', in P. Drechsel, P. Heffer, H. Magen, R. Mikkelsen and D. Wichelns (eds) Managing Water and Fertilizer for Sustainable Agricultural Intensification. International Fertilizer Industry Association (IFA), International Water Management Institute (IWMI), International Plant Nutrition Institute (IPNI), and International Potash Institute (IPI), Paris, France.

Juo, A.S.R., Dabiri, A. and Franzluebbers, K. (1995) 'Acidification of a kaolinitic Alfisol under continuous cropping with nitrogen fertilization in West Africa', Plant and Soil, vol 171, pp. 245-253.

Kamanga, B.C.G., Waddington, S.R., Robertson, M. and Giller, K.E. (2009) 'Risk analysis in maize-legume cropping systems with smallholder farmer resource groups in central Malawi', Experimental Agriculture, vol 46, pp. 1-21.

Koppmair, S., Kassie, M. and Qaim, M. (2017) 'Farm production, market access and dietary diversity in Malawi', Public Health Nutrition, vol 20, pp. 325-335.

Mandiringana, O., Mnkeni, P., Mkile, Z., Van Averbeke, W., Van Ranst, E. and Verplancke, H. (2005) 'Mineralogy and fertility status of selected soils of the Eastern cape province, South Africa', Communications in Soil Science and Plant Analysis, vol 36, pp. 2431-2446.

Misselhorn, A.A. (2005) 'What drives food insecurity in southern Africa? A meta-analysis of household economy studies', Global Environmental Change, vol 15, pp. 33-43.

Msangi, J.P. (2007) 'Land degradation management in Southern Africa', in M.V.K. Sivakumar and N. Ndiang'ui (eds) Climate and Land Degradation. Springer, Berlin.

Mtambanengwe, F. and Mapfumo, P. (2005) 'Organic matter management as an underlying cause for soil fertility gradients on smallholder farms in Zimbabwe', Nutrient Cycling in Agroecosystems, vol 73, pp. 227-243.

Nezomba, H., Mtambanengwe, F., Tittonell, P. and Mapfumo, P. (2015) 'Point of no return? Rehabilitating degraded soils for increased crop productivity on smallholder farms in eastern Zimbabwe', Geoderma, vol 239, pp. 143-155. 
Nyamangara, J., Mugwira, L.M. and Mpofu, S.E. (2000) 'Soil fertility status in communal areas of Zimbabwe in relation to sustainable crop production', Journal of Sustainable Agriculture, vol 16, pp. 15-29.

Pierret, A., Maeght, J-L., Clément, C., Montoroi, J-P., Hartmann, C. and Gonkhamdee, S. (2016) 'Understanding deep roots and their functions in ecosystems: An advocacy for more unconventional research', Annals of botany, vol 118, pp. 621-635.

Pretty, J., Toulmin, C. and Williams, S. (2011). 'Sustainable intensification in African agriculture', International Journal of Agricultural Sustainability, vol 9, pp. 5-24.

Rockström, J., Steffen, W., Noone, K., Persson, A., Chapin, III, F.S., Lambin, E., Lenton, T.M., Scheffer, M., Folke, C., Schellnhuber, H., Nykvist, B., De Wit, C.A., Hughes, T., van der Leeuw, S., Rodhe, H., Sörlin, S., Snyder, P.K., Costanza, R., Svedin, U., Falkenmark, M., Karlberg, L., Corell, R.W., Fabry, V.J., Hansen, J., Walker, B., Liverman, D., Richardson, K., Crutzen, P. and Foley, J. (2009) 'Planetary boundaries: Exploring the safe operating space for humanity', Ecology and Society, vol 14, no 2, p. 32.

Rurinda, J., Van Wijk, M.T., Mapfumo, P., Descheemaeker, K., Supit, I. and Giller, K.E. (2015) 'Climate change and maize yield in southern Africa: What can farm management do?' Global Change Biology, vol 21, pp. 4588-4601.

Rusinamhodzi, L., Corbeels, M., Zingore, S., Nyamangara, J. and Giller, K.E. (2013) 'Pushing the envelope? Maize production intensification and the role of cattle manure in recovery of degraded soils in smallholder farming areas of Zimbabwe', Field Crops Research, vol 147, pp. $40-53$.

Sileshi, G.W., Debusho, L.K. and Akinnifesi, F.K. (2012) 'Can integration of legume trees increase yield stability in rainfed maize cropping systems in Southern Africa?' Agronomy Journal, vol 104, pp. 1392-1398.

Snapp, S.S., Grabowski, P., Chikowo, R., Smith, A., Anders, E., Sirrine, D., Chimonyo, V. and Bekunda, M. (2018) 'Maize yield and profitability tradeoffs with social, human and environmental performance: Is sustainable intensification feasible?' Agricultural Systems, vol 162, pp. 77-88.

Tittonell, P., Corbeels, M., Van Wijk, M.T., Vanlauwe, B. and Giller, K.E. (2008) 'Combining organic and mineral fertilizers for integrated soil fertility management in smallholder farming systems of Kenya: Explorations using the crop-soil model FIELD', Agronomy Journal, vol 100, pp. 1511-1526.

Tittonell, P., Muriuki, A., Shepherd, K.D., Mugendi, D., Kaizzi, K.C., Okeyo, J., Verchot, L., Coe, R. and Vanlauwe, B. (2010) 'The diversity of rural livelihoods and their influence on soil fertility in agricultural systems of East Africa - A typology of smallholder farms', Agricutural Systems, vol 103, pp. 83-97.

Vanlauwe, B., AbdelGadir, A.H., Adewopo, J., Adjei-Nsiah, S., Ampadu-Boakye, T., Asare, R., Baijukya, F., Baars, E., Bekunda, M., Coyne, E., Dianda, M., Dontsop-Nguezet, P.M., Ebanyat, P., Hauser, S., Huising, J., Jalloh, A., Jassogne, L., Kamai, N., Kamara, A., Kanampiu, F., Kehbila, A., Kintche, L., Kreye, C., Larbi, A., Masso, C., Matungulu, P., Mohammed, I., Nabahungu, L., Nielsen, F., Nziguheba, G., Pypers, P., Roobroeck, D., Schut, M., Taulya, G., Thuita, M., Uzokwe, V.N.E., van Asten, P., Wairegi, L., Yemefack, M. and Mutsaers, H.J.W. (2017) 'Looking back and moving forward: 50 years of soil and soil fertility management research in sub-Saharan Africa', International Journal of Agricultural Sustainability, vol 15, pp. 613-631.

Vanlauwe, B., Diels, J., Sanginga, N. and Merckx, R. (2005) 'Long-term integrated soil fertility management in South-western Nigeria: Crop performance and impact on the soil fertility status', Plant and Soil, vol 273, pp. 337-354. 


\section{Bernard Vanlauwe et al.}

Vanlauwe, B., Bationo, A., Chianu, J., Giller, K.E., Merckx, R., Mokwunye, U., Ohiokpehai, O., Pypers, P., Tabo, R., Shepherd, K., Smaling, E., Woomer, P.L. and Sanginga, N. (2010) 'Integrated soil fertility management: Operational definition and consequences for implementation and dissemination', Outlook on Agriculture, vol 39, pp. 17-24.

Vanlauwe, B., Coyne, D., Gockowski, J., Hauser, S., Huising, J., Masso, C., Nziguheba, G. and Van Asten, P. (2014) 'Sustainable intensification and the smallholder African farmer', Current Opinion in Environmental Sustainability, vol 8, pp. 15-22.

Vanlauwe, B., Descheemaeker, K., Giller, K.E., Huising, J., Merckx, R., Nziguheba, G., Wendt, J. and Zingore, S. (2015) 'Integrated soil fertility management in sub-Saharan Africa: Unravelling local adaptation', SOIL, vol 1, pp. 491-508.

Vlek, P.L.G., Le, Q.B. and Tamene, L. (2008) Land Decline in Land-Rich Africa - A Creeping Disaster in the Making. CGIAR Science Council Secretariat, Rome.

Zingore, S., Manyame, C., Nyamugafata, P. and Giller, K.E. (2005) 'Long-term changes in organic matter of woodland soils cleared for arable cropping in Zimbabwe', European Journal of Soil Science, vol 57, pp. 727-736.

Zingore, S., Tittonell, P., Corbeels, M., Van Wijk, M.T. and Giller, K.E. (2011) 'Managing soil fertility diversity to enhance resource use efficiencies in smallholder farming systems: A case from Murewa District, Zimbabwe', Nutrient Cycling in Agroecosystems, vol 90, pp. 87-103. 